\title{
Plasmodium vivax associated severe malaria complications among children in some malaria endemic areas of Ethiopia
}

Tsige Ketema* and Ketema Bacha

\begin{abstract}
Background: Although, Plasmodium vivax is a rare parasite in most parts of Africa, it has significant public health importance in Ethiopia. In some parts of the country, it is responsible for majority of malaria associated morbidity. Recently severe life threatening malaria syndromes, frequently associated to $P$. falciparum, has been reported from $P$. vivax mono-infections. This prompted designing of the current study to assess prevalence of severe malaria complications related to $P$. vivax malaria in Ethiopia.
\end{abstract}

Methods: The study was conducted in two study sites, namely Kersa and Halaba Kulito districts, located in southwest and southern parts of Ethiopia, respectively. Children, aged $\leq 10$ years, who visited the two health centers during the study period, were recruited to the study. Clinical and demographic characteristics such as age, sex, temperature, diarrhea, persistent vomiting, confusion, respiratory distress, hepatomegaly, splenomegaly, hemoglobinuria, and epitaxis were assessed for a total of 139 children diagnosed to have P. vivax mono-infection. Parasitological data were collected following standard procedures. Hemoglobin and glucose level were measured using portable hemocue instrument.

Results: Median age of children was $4.25 \pm 2.95$ years. Geometric mean parasite count and mean hemoglobin level were 4254.89 parasite/ $\mu \mathrm{l}$ and $11.55 \mathrm{~g} / \mathrm{dl}$, respectively. Higher prevalence rate of malaria and severe malaria complications were observed among children enrolled in Halaba district $(P<0.001)$. However, severe parasitemia was higher (72.4\%) among children who visited Serbo health center (Kersa district). Male children had significantly higher risk of malaria infection $(\mathrm{OR}=1.9,95 \% \mathrm{Cl}, 1.08$ to 3.34$)$, while female had higher risk to anemia $(\mathrm{OR}=1.91,95 \% \mathrm{Cl}$, 1.08 - 3.34). The observed number of anemic children was $43 \%$, of which most of them were found in age range from 0-3 years. Furthermore, $P$. vivax malaria was a risk factor for incidence of anemia $(P<0.05)$ in the two sites.

Conclusion: $P$. vivax associated severe malaria complications observed in this study was lower than those reported from other countries. However, incidence of severe malaria complications in one of the sites, Halaba district, where there is highest treatment failure to first line drug, could have significant impact on national malaria prevention and control activities.

Keywords: Anemia, Hemoglobin, Parasitemia, P. vivax, Severe malaria

\section{Background}

Plasmodium vivax is the second important parasite of human malaria widely perceived as causing mild and self-limited illness. Unlike P. falciparum, it has wider geographical distribution. Though the public health importance of this parasite is overshadowed by $P$. falciparum, it is important parasite outside Africa, mainly

\footnotetext{
* Correspondence: tsigeketema@gmail.com

Department of Biology, College of Natural Sciences, Jimma University, P. O.

Box 378, Jimma, Ethiopia
}

in Asia and South America. It causes more than 390 million clinical cases per year [1]. P. vivax, previously thought benign parasite, is recently reported to cause life threatening complications among children from endemic regions such as Indonesia, India and Brazil [2-4]. Some of the reported severe malaria complications are cerebral malaria, dysfunction of different organs, hypoglycemia, jaundice, thrombocytopenia, renal impairment, hepatic dysfunction, acute kidney injury and hypotension [5-9]. 
P. vivax is a chief risk factor for severe anemia among young children in most vivax-endemic areas [2,10]. Though the mechanism of malaria associated severe anemia incidence is multi-factorial, there are established facts on intensive hemolysis of circulating infected RBCs, non infected erythrocytes due to glycosylphosphatidyl-inositol toxin released, and dyserythropoiesis that occur to the effect of different cytokines and other inducer of inflammation such as hemozoin [11-13].

Unlike other countries in Africa, prevalence of P. vivax infection in east Africa, particularly in Ethiopia is higher. In some areas of the country, the prevalence rate exceeds even $70 \%$ of total malaria infections. This was previously accounted to high Duffy blood group positivity of most population of the country [14], but recently contradictory reports are coming $[15,16]$.

Although $P$. vivax malaria is highly prevalent in some parts of Ethiopia and its risk to drug resistance is increasing [17-20], to the authors' knowledge study conducted on $P$. vivax associated severe malaria complication is almost none. Thus, it is rational to assess the current status of $P$. vivax related severe malaria complications in order to estimate the associated burden among biologically risked groups, children, in the endemic areas.

\section{Methods}

\section{Description of the study area}

The study was conducted in two of malaria endemic areas of Ethiopia, namely Kersa and Halaba districts, particularly at Serbo and Halaba Kulito health centers, respectively. The two sites were selected in order to compare incidence of severe $P$. vivax malaria complications in areas where there is intense $P$. vivax transmission (Halaba) and lesser transmission (Kersa). Geographically, Kersa district is located between altitudes ranging from 1,740- 2,660 meter above sea level (masl), which is relatively high land, where as Halaba district is found within altitudes of 1554-2149 masl (Figure 1).

The climatic zones of the districts have mainly consisted of mid-land and low-land. In Halaba, the most important parasite is $P$. vivax and it was responsible for more than $70 \%$ of the total malaria infection; whereas, $P$. falciparum is an important parasite in Kersa district and accounts for about $60 \%$ of all malaria infections in the area $[19,20]$. The mean annual rain fall is $1150 \mathrm{~mm}$ in Kersa and it ranges between $601-1200 \mathrm{~mm}$ in Halaba. In addition, the average annual temperature ranges from 17.6- $22.5^{\circ} \mathrm{C}$ and $11.2-29.6^{\circ} \mathrm{C}$ at Halaba and Kersa, respectively. In both areas, malaria is the most important health problem and the period from September to December is known as malaria peak season. The principal vector that transmits the disease in the country is Anopheles arabiensis.

\section{Study population}

Study participants were children who visited the two health centers during the study period, September- December, 2009 and 2011, and had symptoms of malaria infection. The inclusion criteria used were: children aged $\leq 10$ years, being infected with $P$. vivax mono-infection, without any chronic illness or not admitted to $\mathrm{Tb}$ and ART clinic, without prior medication, having clinical symptoms like fever, chills, malaise, headache, vomiting, history of fever for about 48 hours before admission, and volunteer to participate in the study.

\section{Data collection}

Clinical and demographic data of the study participants (children) were recorded on pre-designed case record form by trained health professionals working at the two health centers. Accordingly, body temperature of each child was measured using digital thermometer; clinical symptoms such as fever, headache, hyperpyrexia, epistaxis, persistent vomiting, impaired consciousness, respiratory distress, hemoglobinuria, splenomegaly, and hepatomegaly were assessed. Children with at least one or more symptoms of severe malaria complications set by WHO [21] were classified as severe $P$. vivax cases.

Data from laboratory tests were collected by experienced laboratory technicians working in the health centers. Accordingly, a drop of blood sample was collected on clean glass slide from lancet pricked finger to prepare thin and thick blood smears in duplicate per patient for microscopic examination. Thick and thin blood smears were stained with $10 \%$ Giemsa ( $\mathrm{pH}=7.2$, for 10 minutes), while thin smears were fixed in methanol prior to Giemsa staining. Malaria parasite was identified by observation of the smears and the morphological appearance of the parasite in the infected RBC under oil immersion objective. Parasite load was calculated after counting asexual parasites per 200 white blood cells (WBC), assuming mean WBC count is $8,000 / \mu \mathrm{l}$. Each blood smear was examined by experienced laboratory technician in the health centers and then re-checked by certified laboratory technician at Jimma University. The degree of parasitaemia was graded as mild, moderate, and severe, when a count was between 1-999 parasite/ $\mu \mathrm{l}, 1000-9999 / \mu \mathrm{l},>10000 / \mu \mathrm{l}$, respectively, following method described by Cheesbrough [22].

From the same pricked finger, few drops of blood samples were taken for measurement of hemoglobin $(\mathrm{Hb})$ and blood glucose concentration (Glu) using handheld portable hemoglobin and glucose analyzer Hemocue ${ }^{\text {тx }}$ (haemoglobinometer, Angelholm, Sweden). Hypoglycemia was considered when blood glucose concentration was $<40 \mathrm{mg} / \mathrm{dl}$. Children with $\mathrm{Hb}$ level $<11 \mathrm{~g} / \mathrm{dl}$ were considered anemic. Briefly, level of anemia was classified as severe, moderate and mild, when $\mathrm{Hb}$ concentration $<5 \mathrm{~g} / \mathrm{dl}$, between 5 and $8 \mathrm{~g} / \mathrm{dl}$, and between 8 and 


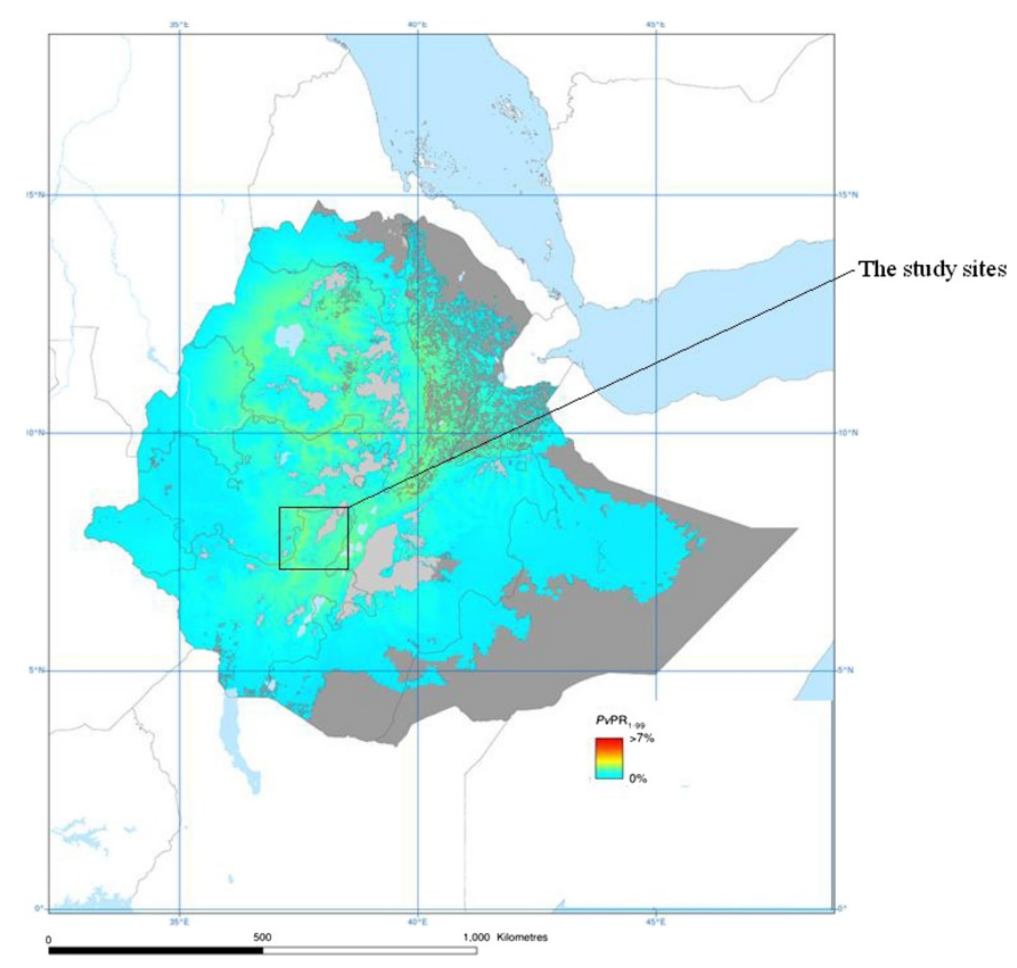

Figure 1 Map of the study sites.

$11 \mathrm{~g} / \mathrm{dl}$, respectively, following the WHO anemia classification for severe P. falciparum malaria [21]. Hyperpyrexia was considered when body temp was $>40^{\circ} \mathrm{C}$. All children were treated with chloroquine $(25 \mathrm{mg}$ base $/ \mathrm{kg}$ ) as per the recommendation of National Malaria Treatment Guideline [23].

\section{Data analysis}

Data was analyzed using SPSS statistical software (version 16.0). Descriptive statistical tests were used for analysis of some clinical, demographic and parasitological data. Associations between variables were evaluated using Pearson correlation test and presented using matrix plot. Odd ratio was employed to describe strength of associations between variables in groups. Independent variables were compared using MannWhitney $U$ test. Median was considered over mean for non-normally distributed variables. In all analysis, significance level was considered at 95\% confidence interval.

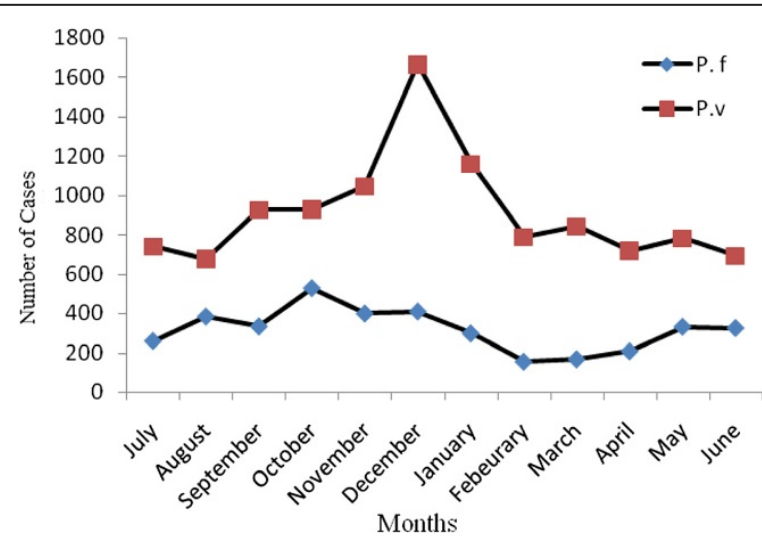

Figure 2 Number of malaria cases observed at Halaba district, SNNPR, Ethiopia. 
Table 1 Clinical and demographic characteristics of children infected with $P$. vivax at Halaba and Kersa districts, Ethiopia

\begin{tabular}{lll}
\hline S.No & Characteristics & Frequency $(\mathbf{n}=\mathbf{1 3 9})$ \\
\hline 1 & Age (median) & $4.25 \pm 2.95$ years \\
2 & Sex & \\
& $\quad$ Male & $58 \%(n=80)$ \\
& $\quad$ Female & $42 \%(n=59)$ \\
3 & Fever at time of enrollment & $55.4 \%(n=77)$ \\
4 & History of fever for about 48 hours & $94.2 \%(n=131)$ \\
5 & Mean body Temp (range) & $37.43\left(36.5-40.7^{\circ} \mathrm{C}\right)$ \\
6 & Vomiting & $39 \%(n=54)$ \\
7 & Diarrhea & $21 \%(n=29)$ \\
8 & Average days of illness (range) & $2.92(2-7$ days $)$ \\
9 & Anemic cases (Hb < 11 g/dl) & $43 \%(n=60)$ \\
10 & Median Hb level (range) & $11.55(4.7-15.2 \mathrm{~g} / \mathrm{dl})$ \\
11 & Median Glucose concentration (range) & $103(36-170 \mathrm{mg} / \mathrm{dl})$ \\
12 & Geometric mean parasite (range) & $4254.89 \pm 8104.3$ \\
& & $(320-36,590$ parasite/ $\mu l)$ \\
\hline
\end{tabular}

\section{Ethical consideration}

The study was ethically approved by Ethical Review Committee of College of Natural Sciences, Jimma University. Written consent/assent was obtained from guardians of the study participants prior to data collection.

\section{Results}

\section{Malaria prevalence}

During the study period, a total of 1497 blood samples were collected from presumptive malaria cases aged $\leq 10$ years. About 31.9\% (478/1497) were positive for malaria infection. Among these, 32.64\% (156/478) and 67.36\%
(322/478) were infected with $P$. vivax and $P$. falciparum, respectively. Based on the inclusion criteria, a total of 139 children with P.vivax who fulfilled the inclusion criteria ( $\mathrm{n}=58$ from Kersa and $\mathrm{n}=81$ from Halaba) were retrospectively analyzed. The rest (17/156) were excluded from the study due to prior medication, lack of consent from their guardians, and few due to admission to $\mathrm{Tb}$ clinic. The prevalence of $P$. vivax malaria was significantly different $(\mathrm{P}<0.05)$ at Halaba district and significantly higher among children aged $\leq 5$ years $(\mathrm{P}<0.01)$. Sample composition in terms of sex and age did not differ significantly ( $p>0.05$ ) between the two study sites. Even if the overall malaria prevalence shows a declining trend across the country, the number of malaria patients is still high in Halaba district (Figure 2).

\section{Clinical and demographic characteristics}

Based on the observed clinical and demographic characteristics, median age of the children was $4.25 \pm 2.95$ years. Male children had significantly higher risk of malaria infection (OR $=1.9,95 \% \mathrm{CI}, 1.08$ to 3.34). At the time of admission, about $39 \%(54 / 139)$ and $21 \%(29 / 139)$ of the children had vomiting and diarrhea, respectively. Though most children, $94.2 \%$ (131/139) had a history of fever for the past 48 hours, only $55.4 \%(77 / 139)$ of them were febrile and had axillary temperature $\geq 37.5^{\circ} \mathrm{C}$ during enrollment. The median $\mathrm{Hb}$ and Glu concentration were $11.55(4.7-15.2 \mathrm{~g} / \mathrm{dl})$ and $103(36-170 \mathrm{mg} / \mathrm{dl})$, respectively, while the geometric mean parasite count (asexual stage) and average body temperature were 4254.89 (320-36,590 parasite/ $\mu \mathrm{l})$ and $37.43\left(36.5-40.7^{\circ} \mathrm{C}\right)$, respectively (Table 1$)$.

Pearson correlation analysis revealed that age of children was negatively correlated to parasite count $(\mathrm{r}=-0.2358$, $\mathrm{p}<0.05$ ) but had positive correlation to hemoglobin levels. Accordingly, as age of children increased the parasite
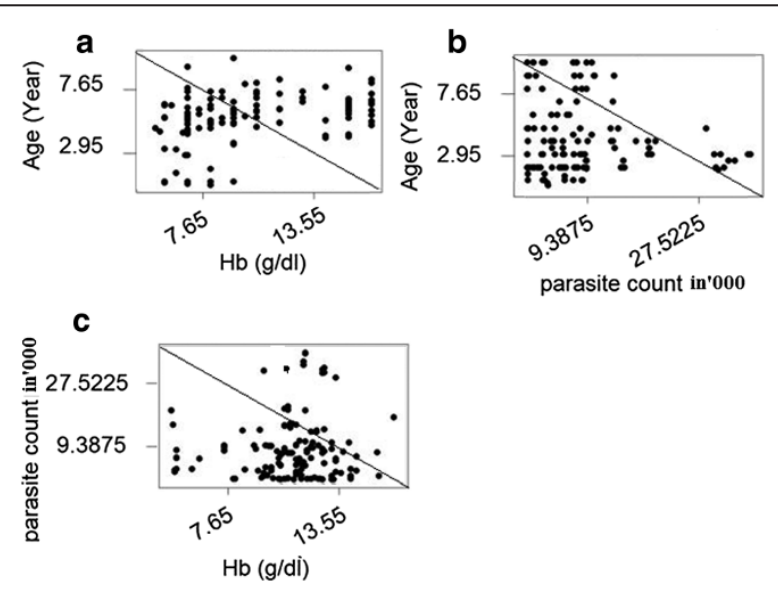

Figure 3 Association between age, hemoglobin level and parasite counts among children infected with $P$. vivax at Halaba and Kersa districts, Ethiopia. 
Table 2 Prevalence of severe malaria complications among $P$. vivax infected children at Halaba and Kersa districts, Ethiopia

\begin{tabular}{llll}
\hline S. No & Characters & \multicolumn{2}{c}{ Sites } \\
\cline { 3 - 4 } & & Halaba & Kersa \\
\hline 1 & Malaria prevalence & $\mathrm{n}=81(58.27 \%)$ & $\mathrm{n}=58(41.72 \%)$ \\
2 & Anemic children $(\mathrm{Hb}<11 \mathrm{~g} / \mathrm{dl})$ & $\mathrm{n}=37(45.68 \%)$ & $\mathrm{n}=23(39.65 \%)$ \\
3 & Severe anemia $(\mathrm{Hb}<5 \mathrm{~g} / \mathrm{dl})$ & 6 & 2 \\
4 & Hypoglycemia $(\mathrm{Glu}<40 \mathrm{mg} / \mathrm{dl})$ & 2 & 0 \\
5 & Severe parasitemia & 8 & 21 \\
6 & (>10,000 Para/ $\mathrm{ll})$ & & \\
7 & Respiratory distress & 2 & 1 \\
8 & Hyperpyrexia & 1 & 3 \\
9 & Persistent vomiting & 1 & 1 \\
10 & Domiting & $21 / 81(25.9 \%)$ & $27 / 58(46.55 \%)$ \\
11 & Febrile & $23 / 81(28.39 \%)$ & $14 / 58(24.1 \%)$ \\
\hline
\end{tabular}

count decreased, while the level of $\mathrm{Hb}$ increased $(\mathrm{r}=0.31$, $\mathrm{P}<0.001)$. However, there was no significant differences $(\mathrm{r}=0.057, \mathrm{p}>0.05)$ between $\mathrm{Hb}$ level and parasite count (Figure 3).

\section{Severe malaria}

Among 139 children, a total of 19 (13.67\%) fulfilled at least one of the WHO criteria for severe malaria [21]. Some of these syndromes were; persistent vomiting $(10.5 \%, \mathrm{n}=2)$, respiratory distress $(15.8 \%, \mathrm{n}=3)$, hypoglycemia $(10.5 \%, n=2)$, hyperpyrexia or temperature $>40^{\circ} \mathrm{C}$ $(21 \%, \mathrm{n}=4)$, and severe anemia $(42 \%, \mathrm{n}=8)$. But, none had symptoms like hepatomegaly, splenomegaly, epistaxis, confusion or coma, and hemoglobinuria or discoloration of urine. Severe malaria syndromes were significantly higher $(\mathrm{OR}=3.16,95 \% \mathrm{CI}, 1.77-5.6)$ among children who visited Halaba Kulito health center (Table 2). Children with severe parasitemia, parasite count $>10,000$ parasite $/ \mu$ l, were significantly higher $(\mathrm{P}<0.001)$ in Kersa (Serbo health center). Likewise, vomiting cases were significantly higher $(\mathrm{OR}=2.52,95 \% \mathrm{CI}=1.39-4.57)$ among children enrolled at Serbo health centre. However, incidence of diarrhea and fever were not significantly different $(P>0.05)$ between the two sites. Number of children with more than one severe malaria symptoms were very few $(n=6)$ and most of them had severe anemia with other syndromes including persistent vomiting $(\mathrm{n}=1)$, respiratory distress $(\mathrm{n}=3)$, and hyperpyrexia $(\mathrm{n}=2)$.

The frequency of incidence of anemia $(43 \%, \pm 9.7$, $33.3-53 \%)$ was significantly higher $(\mathrm{P}<0.05)$ among children within the age range of $0-3$ years than other categories (Table 3). Severe anemia was observed in eight children aged between $0-3$ years $(n=7)$ and 4 years $(n=1)$. Most severe anemic cases $(75 \%, n=6 / 8)$ were observed in Halaba district. In terms of sex, female children had significantly higher risk of anemia $(\mathrm{OR}=1.91$, 95\% CI, 1.08 - 3.34). Severe parasitemia was significantly different $(\mathrm{OR}=0.1854,95 \% \mathrm{CI}, 0.088-0.39)$ among anemic children. The study showed that $P$. vivax malaria was a risk factor for incidence of anemia $(P<0.05)$.

Severe parasitemia was observed in 41 children with almost similar proportion in all age groups except for children $<3$ years $(43.9 \%, \mathrm{n}=18 / 41)$ who was found to have higher parasitemia. $\mathrm{Hb}$ level and parasite count of children in the age category of 0-3 years was compared with those in the highest age category ( $>6$ years) using Mann-Whitney $U$ test. The result showed that $\mathrm{Hb}$ level was significantly different $(\mathrm{P}<0.01)$ between the two age categories, but parasite count didn't show significant difference $(P>0.05)$. Parasite counts of all children with severe anemia were found in the range of 1000-9999 parasite/ $\mu \mathrm{l}$.

\section{Discussion}

The prevalence rate of malaria observed in this study was $31.9 \%$, which was much lower than the very recent report from Nigeria (81.9\%) [24]. This might be due to the intense and diverse malaria control strategies undertaken in most parts of Ethiopia. The intervention made so far has significantly reduced prevalence of malaria in some endemic areas. As evidence, during the second phase of this study (in 2011), the numbers of malaria patients observed at Serbo health center were very few for recruitment in the study. At Halaba district, however, though the trend of malaria prevalence appears declining, the numbers of malaria patients visiting the health center were still high. For instance, in the same year (2011), among a total of 27,499 malaria suspected patients, $14,775(53.73 \%)$ were

Table 3 Incidence of severe anemia, parasitemia and hypoglycemia among children infected with $P$. vivax at Halaba and Kersa districts, Ethiopia

\begin{tabular}{|c|c|c|c|c|c|c|c|c|c|}
\hline \multirow[t]{2}{*}{ No } & \multirow[t]{2}{*}{ Age (year) } & \multicolumn{3}{|c|}{ Hb level (g/dl) } & \multicolumn{3}{|c|}{ Parasite count $/ \mu \mathrm{l}$} & \multicolumn{2}{|c|}{ Glucose level (mg/dl) } \\
\hline & & $<5$ & $5<\mathrm{Hb}<8$ & $8<\mathrm{Hb}<11$ & $1-999$ & $1000-9999$ & $>10000$ & $<40$ & $>40$ \\
\hline 1 & $0-3$ & 7 & 11 & 15 & 7 & 28 & 18 & 2 & 35 \\
\hline 2 & $>3-6$ & 1 & 5 & 10 & 11 & 22 & 13 & 0 & 33 \\
\hline \multirow[t]{2}{*}{3} & $>6-10$ & 0 & 0 & 11 & 15 & 15 & 10 & 0 & 30 \\
\hline & Total & 8 & 16 & 36 & 33 & 65 & 41 & 2 & 137 \\
\hline
\end{tabular}


found positive. Out of these, 10,957 (39.8\%) were due to $P$. vivax and the rest were accounted to P. falciparum (Unpublished data, Annual Report on Malaria Prevalence by Halaba Kulito health center, 2011).

Most of the children enrolled in this study were found in age group $\leq 5$ years. In this age category higher load of parasitemia and incidence of severe anemia, but lower concentration of hemoglobin was observed. This strengthens the fact that children in this age group who live in holo or hyperendemic areas are biologically risked group [25]. This is because of the development of poor immunity against the disease [21], but as they get older and repeatedly exposed to the disease they gradually develop protective immunity to malaria [26].

Percentage of anemic cases documented in this study (43\%) was higher than the earlier 34\% reported from children [27] and 30.5\% from among adults [28] in South-Western India. Usually anemia is associated with intense hemolysis of RBCs due to higher parasitemia such as in the case of infection with $P$. falciparium. However, due to selective preference to only young RBCs by P.vivax, it appears that the number of hemolyzed RBC during P.vivax is minimal. Thus, the incidence of anemia might occur as a result of rigor inflammatory reactions due to pro-inflammatory response and cytokines activation [29] and less deformability of RBCs during $P$. vivax infection $[30,31]$. On the other hand, the rate of non infected RBCs hemolysis for every infected RBC destroyed could contribute to the incidence of anemia as number of nonparasitized RBCs removed from circulation during $P$. vivax is much higher $(\sim 32)$ than P.falciparum $(\sim 8)[32,33]$.

Frequency of P.vivax associated severe malaria complications documented in this study (13.67\%) was less than those report from Eastern Sudan (18\%) from among children admitted to hospital due to severe P. vivax malaria [8], but slightly higher than those from Venezuela (10.26\%) [34]. In agreement with report from Eastern Sudan [8], the most prevalent severe malaria complication observed in this study was severe anemia (36.36\%) followed by hyperpyrexia, respiratory distress and persistent vomiting. Incidence of hypoglycemia was minimal. Other severe malaria symptoms including hepatomegaly, splenomegaly, confusion, epistaxis and persistent vomiting were not observed, except the respiratory distress cases which was in agreement with the recent report from India [35].

With regard to sites, the numbers of children with severe malaria complications were higher among those children who visited Halaba Kulito health center, the site where the highest (13\%) treatment failure to chloroquine (the first line drug) by P.vivax malaria was documented [20]. Siliva-Filho et al. [36] elaborated that when there is drug resistance trait in a certain area, it increases peripheral parasitemia for a longer time and enhance hemolysis of RBCs. As a consequence, persistent of the parasite in hosts blood can increase incidence of severe malaria syndromes. This is evidenced by frequent occurrence of severe anemia in such localities [37]. On the other hand, intense disease transmission in Halaba district might have contributed to the higher severe malaria cases. It is also affirmed that in an area where there is intense malaria transmission there is high incidence of severe malaria morbidity which results in higher hospital admission among young children [38].

\section{Conclusion}

As P.vivax malaria parasite had already developed resistant to the first line drug, chloroquine, in one of these study sites, underestimation of complications caused by $P$. vivax malaria could have significant impact on current malaria control and prevention activities being under taken in the districts. Thus, it calls for special attention and frequent surveillance by concerned bodies in order to achieve the sought national malaria reduction plan.

\section{Competing interests}

The authors declare that they have no competing interest.

\section{Authors' contributions}

Both authors equally involved in all phases of the study including designing of the study, data collection and monitoring, data analysis, and write-up of the manuscript. Both authors read and approved the final manuscript.

\section{Acknowledgments}

The authors would like to thank officials and health professionals working at Halaba and Serbo health centers, the study participants and their guardians. The study was financially supported by Jimma University, Ethiopia.

Received: 22 January 2013 Accepted: 4 July 2013

Published: 8 July 2013

\section{References}

1. Price RN, Tjitra E, Guerra CA, Yeung S, White NJ, Anstey NM: Vivax malaria: neglected andnot benign. Am J Trop Med Hyg 2007, 77:79-87.

2. Tjitra E, Anstey NM, Sugiarto P, Warikar N, Kenangalem E, Karyana M, Lampah DA, Price RN: Multidrug-resistant Plasmodium vivax associated with severe and fatal malaria: a prospective study in Papua, Indonesia. PLoS Med 2008, 5:e128.

3. Kochar DK, Das A, Kochar SK, Saxena V, Sirohi P, Garg S, Kochar A, Khatri MP, Gupta V: Severe Plasmodium vivax malaria: a report on serial cases from Bikaner in northwestern India. Am J Trop Med Hyg 2009, 80:194-198.

4. Alexandre MA, Ferreira CO, Siqueira AM, Magalhães BL, Mourao MP, Lacerda MV, Alecrim MD: Severe Plasmodium vivax malaria, Brazilian Amazon. Emerg Infect Dis 2010, 16:1611-1614.

5. Tanwar GS, Khatri PC, Kochar A, Kochar SK, Middha S, Tanwar G, Khatri N, Pakalapati D, Garg S, Das A, Kochar DK: Clinical profiles of 13 children with Plasmodium vivax cerebral malaria. Ann Trop Paediatr 2011, 31(4):351-356.

6. Manning L, Laman M, Law I, Bona C, Aipit S, Teine D, Warrell J, RosanasUrgell A, Lin E, Kiniboro B, Vince J, Hwaiwhanje I, Karunajeewa H, Michon P, Siba P, Mueller I, Davis TM: Features and Prognosis of Severe Malaria Caused by Plasmodium falciparum, Plasmodium vivax and Mixed Plasmodium Species in Papua New Guinean Children. PLoS One 2011, 6(12):e29203.

7. Osonuga OA, Osonuga AA, Osonuga IO, Derky KL: Prevalence of hypoglycemia among severe malaria children in rural Africa population. Asian Pac J Trop Dis 2011, 3:192-194.

8. Mahgoub H, Gasim GI, Musa IR, Adam I: Severe Plasmodium vivax malaria among sudanese children at New Halfa Hospital. Eastern Sudan Parasit Vec 2012, 5:154. 
9. Kute VB, Trivedi HL, Vanikar AV, Shah PR, Gumber MR, Patel HV, Goswami JG, Kanodia KV: Plasmodium vivax malaria-associated acute kidney injury, India, 2010-2011. Emerg Infect Dis 2012, 18(5):842-845. doi:10.3201/ eid1805.111442.

10. Genton BV, D'Acremont V, Rare L, Baea K, Reeder JC MP, Alpers MP, Muller I: Plasmodium vivax and mixed infections are associated with severe malaria in children: a prospective cohort study from Papua New Guinea. PLoS Med 2008, 5:127.

11. Brattig NW, Kowalsky K, Liu X, Burchard GD, Kamena F, Seeberger PH: Plasmodium falciparum glycosylphosphatidylinosi-tol toxin interacts with the membrane of non-parasitized red blood cells: a putative mechanism contributing to malaria anemia. Microbes Infect 2008, 10:885-891.

12. Chasis JA, Mohandas N: Erythroblastic islands: niches for erythropoiesis. Blood 2008, 112:470-478.

13. Haldar K, Murphy SC, Milner DA, Taylor TE: Malaria: mechanism of Erythrocytic infection andpathological correlates of severe disease. Annu Rev Pathol Mech Dis 2007, 2:217-249.

14. Miller LH, Mason SJ, Clyde DF, McGinniss MH: The resistance factor to Plasmodium vivax in blacks. The Duffy-blood-group genotype, FyFy. N Engl J Med 1976, 295:302-304.

15. Ryan JR, Stoute JA, Amon J, Dunton RF, Mtalib R, Koros J, Owour B, Luckhart S, Wirtz RA, Barnwell JW, Rosenberg R: Evidence for transmission of Plasmodium vivax among a Duffy antigen negative population in Western Kenya. AmJTrop Med Hyg 2006, 75:575-581.

16. Cavasini CE, Mattos LC, Couto AA, Bonini-Domingos CR, Valencia SH, Neiras WC, Alves RT, Rossit AR, Castilho L, Machado RL: Plasmodium vivax infection among Duffy antigen-negative individuals from the Brazilian Amazon region: an exception? Trans R Soc Trop Med Hyg 2007, 101:1042-1044.

17. Tulu NA, Webbeg RH, Schellenberg JA, Bradley DJ: Failure of chloroquine treatment for malaria in the highlands of Ethiopia. Trans $R$ Soc Trop Med Hyg 1996, 90:556-557.

18. Teka H, Petros B, Yamuah L, Tesfaye G, Elhassan I, Muchohi S, Kokwaro G, Abraham A: Chloroquine-resistant Plasmodium vivax malaria in Debre Zeit, Ethiopia. Malar J 2008, 7:220.

19. Ketema T, Bacha K, Birhanu T, Petros B: Chloroquine resistant Plasmodium vivax Malaria in Serbo town, Jimma zone, south west Ethiopia. Malar J 2009, 8:177.

20. Ketema T, Getahun K, Bacha K: Therapeutic efficacy of chloroquine against Plasmodium vivax malaria in Halaba district, SNNPR, Ethiopia. Parasit Vector 2011, 4:46.

21. WHO: Severe and complicated malaria. Trans R Soc Trop Med Hyg 2000, 94(1):1-90.

22. Cheesbrough M: District Laboratory practice in Tropical countries. 2nd edition. Cambridge: Cambridge University Press; 2005:24451.

23. FDRE: National Malaria Guideline. 3rd edition. Ethiopia: Addis Ababa; 2012. 155pp.

24. Oladeinde $\mathrm{BH}$, Omoregie R, Olley M, Anunibe J, Onifade A, Oladeinde O: Malaria and Anemia among Children in a Low Resource Set $\neg$ ting In Nigeria. Iranian J Parasito 2012, 7(3):31-37.

25. Le Port A, Cottrell G, Martin-Prevel Y, Migot-Nabias F, Cot M, Garcia A: First malaria infections in a cohort of infants in Benin: biological, environmental and genetic determinants. Description of the study site, population methods and preliminary results. BMJ 2012, 2:e000342.

26. Doolan DL, Dobano C, Baird JK: Acquired Immunity to Malaria. Clin Microbiol Rev 2009, 22(1):13-36.

27. Singh H, Naha K, Dasari S, Prabhu M: Spectrum of complications associated with Plasmodium vivax infection in a tertiary hospital in South-Western India. Asian Pac J Trop Med 2012, 5:79-82.

28. Naha K, Dasari S, Prabhu M: Spectrum of complications associated with Plasmodium vivax infection in a tertiary hospital in South-Western India. Asian Pac J Trop Med 2012, 5(1):79-82

29. Andrade BB, Reis-Filho A, Souza-Neto SM, Clarencio J, Camargo LM, Barral A, Barral-Netto M: Severe Plasmodium vivax malaria exhibits marked inflammatory imbalance. Malar J 2010, 9:13.

30. Anstey NM, Russell B, Yeo TW, Price RN: The pathophysiology of vivax malaria. Trends Parasitol 2009, 25:220-226.

31. Handayani S, Chiu DT, Tjitra E, Kuo JS, Lampah D, Kenangalem E, Renia L, Snounou G, Price RN, Anstey NM, Russell B: High deformability of Plasmodium vivaxinfected red blood cells undermicrofluidic conditions. J Infect Dis 2009, 199:445-450.
32. Colins W, Jeffery GM, Roberts JQ: A retrospective examination of anemia during infection of humans with Plasmodium vivax. Am J Trop Med Hyg 2003, 68:410-412.

33. Boutlis C, Yeo TW, Anstey NM: Malaria tolerance - for whom the cell tolls? Trends Parasitol 2006, 22:371-377.

34. Rodríguez-Morales AJ, Sánchez E, Vargas M, Piccolo C, Colina R, Arria M: Anemia and Thrombocytopenia in Children with Plasmodium vivax Malaria. J Trop Pediatr 2005, 52(1):49-51.

35. Kaushik JS, Gomber S, Dewan P: Clinical and Epidemiological Profiles of Severe Malaria in Children from Delhi. India J Health Popul Nutr 2012, 30(1):113-116.

36. Filho FS, Lima-Arcanjo AR, Chehuan YM, Costa MR, Martinez-Espinosa FE, Vieira JL, Barbosa MG, Alecrim WD, Alecrim MG: Chloroquine-resistant Plasmodium vivax, Brazilian Amazon. Emerg Infect Dis 2007, 13:1125-1129.

37. Price RN, Douglas NM, Anstey NM: New developments in Plasmodium vivax malaria: severe disease and the rise of chloroquine resistance. Curr Opin Infect Dis 2009, 22(5):430-435.

38. Carneiro I, Roca-Feltrer A, Griffin JT, Smith L, Tanner M, Schellenberg AJ, Greenwood B, Schellenberg D: Age-patterns of malaria vary with severity, transmission intensity and seasonality in sub-Saharan Africa: A systematic review and pooled analysis. PLoS One 2010, 5:e8988.

doi:10.1186/1471-2458-13-637

Cite this article as: Ketema and Bacha: Plasmodium vivax associated severe malaria complications among children in some malaria endemic areas of Ethiopia. BMC Public Health 2013 13:637.

\section{Submit your next manuscript to BioMed Central and take full advantage of:}

- Convenient online submission

- Thorough peer review

- No space constraints or color figure charges

- Immediate publication on acceptance

- Inclusion in PubMed, CAS, Scopus and Google Scholar

- Research which is freely available for redistribution

Submit your manuscript at www.biomedcentral.com/submit
C) Biomed Central 